(c) American Dairy Science Association, 2004.

\title{
Analysis of the Relationship Between Type Traits and Functional Survival in US Holstein Cattle Using a Weibull Proportional Hazards Model
}

D. Z. Caraviello, K. A. Weigel, and D. Gianola

Department of Dairy Science, University of Wisconsin, Madison 53706

\begin{abstract}
Survival analysis with a Weibull proportional hazards model was used to evaluate the effects of 15 linear type traits, 5 composite traits, and final score on the functional longevity of US Holstein cows. Culling data and type classification scores (measured in first lactation) from 891,524 cows with first calving from 1993 to 2000 were used. The data were divided into 9 geographical regions to determine whether the relationship between type traits and longevity differed according to climate or management system. Functional survival was defined as the number of days from first calving until culling or censoring, after correction for 305-d mature equivalent combined fat and protein yield. The Weibull model included time-dependent effects of herdyear-season, parity-stage of lactation, and within herdyear quintile ranking for combined fat and protein yield (nested within biennium), as well as time-independent effects of age at first calving and type classification score (type traits were analyzed one at a time). Type classification scores were rounded to the nearest 5 points, and the impact of each type trait on functional survival in each region was evaluated. Mean failure time ranged from $694 \mathrm{~d}$ in the South to $758 \mathrm{~d}$ in the North East. Risk of culling differed by region for several linear type traits, and differences were greatest for regions that were most dissimilar in climate and herd management (e.g., South East, East North Central, and West). Udder depth, fore udder attachment, udder cleft, and rear legs side view were consistently associated with functional longevity, regardless of region, but, the importance of some secondary traits, such as stature or dairy form, differed by region. The survival model applied in this study easily described both linear and nonlinear relationships between type traits and longevity while accounting for important time-dependent and time-independent explanatory variables.
\end{abstract}

Received August 25, 2003.

Accepted March 14, 2004.

Corresponding author: K. A. Weigel; e-mail: weigel@calshp.cals. wisc.edu.
(Key words: survival, Holstein, type trait, proportional hazard)

\section{INTRODUCTION}

The importance of type traits as early predictors of longevity has been evaluated in several studies using different methodologies (Short and Lawlor, 1992; Larroque and Ducrocq, 1999; Schneider et al., 1999; Cruickshank et al., 2002). Type traits can be measured in first lactation, and most have moderate to high heritability, ranging from 0.15 to 0.4 (Short and Lawlor, 1992). Conversely, longevity typically has low heritability, ranging from about 0.05 to 0.2 , and information is often available after selection decisions have been made. Estimated breeding values for type traits can be combined with information regarding daughters' time of death or culling to obtain useful longevity evaluations early in a sire's life (Weigel et al., 1998), and this approach is used in current US genetic evaluations for length of productive life. Because data for type traits are already collected in most major dairy countries, the marginal cost of using these traits as indirect predictors of survival is minimal.

Determining whether differences exist between geographical regions in the relative importance of linear type traits, with respect to cow survival, may be important when using these traits in a selection program. For example, certain traits might be more important in large Western US herds than in small Northeastern US herds, and traits that are important in the cool climate of the Northwest might be different from those that are important in the subtropical climate of the Southeast. Knowledge of such differences would facilitate development of specific breeding recommendations or selection indices for different regions or herd management systems. Countries that import genetic material from the United States might also benefit from knowledge of the relative importance of specific type traits under different production conditions.

Survival analysis using a Weibull proportional hazards model can offer several advantages in evaluation of longevity data. For example, models of this type allow 
Table 1. States comprising each of the 9 US standard regions for temperature and precipitation.

\begin{tabular}{|c|c|c|}
\hline North East & South East & Central \\
\hline $\begin{array}{l}\text { Maine } \\
\text { New Hampshire } \\
\text { Vermont } \\
\text { Massachusetts } \\
\text { Rhode Island } \\
\text { Connecticut } \\
\text { New York } \\
\text { New Jersey } \\
\text { Pennsylvania } \\
\text { Delaware } \\
\text { Maryland }\end{array}$ & $\begin{array}{l}\text { Virginia } \\
\text { North Carolina } \\
\text { South Carolina } \\
\text { Georgia } \\
\text { Florida } \\
\text { Alabama }\end{array}$ & $\begin{array}{l}\text { Ohio } \\
\text { Indiana } \\
\text { Illinois } \\
\text { Missouri } \\
\text { West Virginia } \\
\text { Kentucky } \\
\text { Tennessee }\end{array}$ \\
\hline East North Central & West North Central & South \\
\hline $\begin{array}{l}\text { Michigan } \\
\text { Wisconsin } \\
\text { Iowa } \\
\text { Minnesota }\end{array}$ & $\begin{array}{l}\text { North Dakota } \\
\text { South Dakota } \\
\text { Nebraska } \\
\text { Montana } \\
\text { Wyoming }\end{array}$ & $\begin{array}{l}\text { Kansas } \\
\text { Mississippi } \\
\text { Arkansas } \\
\text { Louisiana } \\
\text { Oklahoma } \\
\text { Texas }\end{array}$ \\
\hline South West & North West & West \\
\hline $\begin{array}{l}\text { Colorado } \\
\text { New Mexico } \\
\text { Arizona } \\
\text { Utah }\end{array}$ & $\begin{array}{l}\text { Idaho } \\
\text { Washington } \\
\text { Oregon }\end{array}$ & $\begin{array}{l}\text { Nevada } \\
\text { California }\end{array}$ \\
\hline
\end{tabular}

the inclusion of time-dependent covariates, accommodation of skewed or unknown distributions of survival times, and proper handling of censored (incomplete) longevity records of animals that are sold for dairy purposes and animals that are still alive at the time of analysis (Beilharz et al., 1993; Smith and Quaas, 1984; Ducrocq, 1987; Larroque and Ducrocq 1999; Vukasinovic, 1999).

Defining contemporary groups based on herd-yearseason of first calving (Short and Lawlor, 1992; Cruickshank et al., 2002) may ignore important changes in herd management conditions that occur during a particular animal's lifetime. Changes such as herd expansion, modernization of facilities, adoption of bST, or implementation of an estrus synchronization may affect a cow's risk of culling during a particular period but might not affect all lactations of all cows with first calving in a particular herd-year-season class. Adjusting for milk production in a time-dependent manner is also sensible because the current risk of culling for a particular cow probably depends more heavily on her current production level than on her first lactation production or her average production across all lactations. Inclusion of time-dependent explanatory variables gives us the flexibility in modeling environmental influences on longevity, because we can assign numerous "change times" for each variable in the model.

The objective of this study was to evaluate the impact of linear type traits, major breakdown scores, and final score on the functional longevity of US Holstein cows in each of 9 geographical regions.

\section{MATERIALS AND METHODS}

\section{Data}

The continental United States was divided in 9 geographical regions based on temperature and precipitation data provided by the National Climatic Data Center. The states constituting each region are listed in Table 1. Longevity and milk production data were obtained from the USDA Animal Improvement Programs Laboratory, and type classification scores were obtained from the Holstein Association USA. After editing, information from 891,524 cows with first calving from 1993 to 2000 was used, and these data were divided into 9 geographical regions (each analyzed independently). Cows were required to have type classification scores during first lactation, as well as valid sire identification and age at first calving between 18 and 42 mo of age. Lactation records were assigned to quintiles based on within herd-year, 305-d mature equivalent (combined) fat and protein production. Linear type scores, major breakdown (composite) scores, and final (overall conformation) score were rounded to the nearest 5 points. Because of the high phenotypic correlations between some type traits (e.g., strength and body depth), the impact of each type trait, major breakdown, and final score on functional longevity was assessed separately in each region.

Survival time was defined as days from first calving until culling or censoring. Records from cows that were sold (to another herd) for dairy purposes were considered as censored at the time of sale, as were cows in herds that discontinued milk recording and cows that were still alive at the time of evaluation. Cows with complete 305-d lactation records that did not calve again within 6 mo were considered as dead and were treated as uncensored. Because voluntary culling (for low production) is an important reason for disposal, our analysis was based on functional survival. Functional survival was defined as the ability to delay involuntary culling, and it was approximated by correcting true survival time for within-herd-year production ranking.

\section{Model}

The model for analysis of functional survival was

$$
h_{i j k l m}(t)=\mathrm{h}_{0}(t) \exp \left[P_{i}(t)+\mathrm{A}_{j}+M_{k}(t)+\mathrm{c}_{l}(t)+\mathrm{T}_{m}\right]
$$

where 
Table 2. Number of cows included in the analysis, mean failure time (days from first calving until culling), percentage of censored records, estimated scale parameter $(\rho)$, and estimated parameter of the distribution of herd-year-season contemporary groups $(\gamma)$ for each of the 9 geographical regions.

\begin{tabular}{|c|c|c|c|c|c|c|}
\hline Region & Cows, no. & Herds, no. & $\begin{array}{l}\text { Mean } \\
\text { failure time, } d\end{array}$ & $\begin{array}{l}\text { Censored } \\
\text { records, \% }\end{array}$ & $\rho$ & $\gamma$ \\
\hline North East & 272,766 & 5894 & 758 & 44.6 & 0.80 & 9.7 \\
\hline South East & 43,037 & 742 & 715 & 40.1 & 0.36 & 7.7 \\
\hline Central & 93,321 & 1964 & 726 & 41.6 & 0.79 & 10.3 \\
\hline East North Central & 263,097 & 6764 & 716 & 42.5 & 0.58 & 5.5 \\
\hline West North Central & 14,826 & 319 & 702 & 42.3 & 0.41 & 6.0 \\
\hline South & 33,585 & 678 & 694 & 42.4 & 0.44 & 4.8 \\
\hline South West & 20,991 & 246 & 729 & 42.1 & 0.38 & 4.2 \\
\hline North West & 42,431 & 522 & 732 & 41.3 & 0.65 & 7.1 \\
\hline West & 107,470 & 866 & 713 & 40.8 & 0.60 & 5.0 \\
\hline
\end{tabular}

$h_{i j k l m}(t)=$ hazard function of a particular animal at time t;

$h_{0}(t)=$ Weibull baseline hazard function;

$P_{i}(t)=$ time-dependent effect of parity and stage of lactation (parities $1,2,3,4$, and $\geq 5$ and stage of lactation of $<45,45$ to 270 , and $>270$ DIM);

$A_{j}=$ time-independent effect of age at first calving;

$M_{k}(t)=$ time-dependent effect of within herd-year (of calving) quintile ranking for mature equivalent 305-d combined fat and protein yield in each lactation, nested within biennium (1993 to1994, 1995 to 1996,1997 to 1998 , or 1999 to 2000) to account for differences in the voluntary culling rate over time;

$c_{l}(t)=$ time-dependent random effect of contemporary (herd-year-season) group, with change points of January 1, May 1, and September 1 in each year; and

$T_{m}=$ time-independent effect of type classification score, rounded to the nearest 5 points.

Additive genetic effects of the animal and/or its sire were not included in the model because our objective was to determine the relationship between each animal's physical conformation (i.e., phenotype) in first lactation and its ability to resist involuntary culling in subsequent lactations. Accounting for the genetic merit of each cow's sire (for type or longevity) would remove a portion of the differences between animals, thereby limiting our inferences to environmental influences on survival (Larroque and Ducrocq, 1999). The aforementioned model was applied to longevity data from each region, and specific estimates of $\rho$ (the shape parameter of the Weibull distribution) and $\gamma$ (the parameter of the log-gamma distribution of contemporary group effects) were obtained for each region. The Survival Kit Version 3.12, a set of FORTRAN programs written by Ducrocq and Sölkner (1994), was used. The 25 largest herds in each region were used for parameter estimation, such that herd-year-season classes with few animals (possibly all censored) were minimized. Because selecting only large herds for parameter estimation could introduce bias into comparisons of $\rho$ and $\gamma$ between regions, we subsequently verified our estimates of these parameters using random samples of herds with $\geq 100$ cows from each region (results not shown).

\section{RESULTS AND DISCUSSION}

Estimates of $\rho$, the shape parameter of the Weibull distribution, varied from 0.36 in the South East region to 0.80 in the North East region. Similarly, estimates of $\gamma$, the parameter of the log-gamma distribution of contemporary group effects, ranged from 4.2 in the South West region to 10.3 in the Central region. Heterogeneity in these parameters likely reflects differences in the average survival curve between regions, as well as differences in the amount of variation in cow survival that can be attributed to herd-year-season management groups.

Table 2 shows a summary of the data for each geographical region. Of the 891,524 survival records, $40.1 \%$ $(298,793)$ were right censored. The highest mean failure time was $758 \mathrm{~d}$ after first calving in the North East; the lowest mean failure time was $694 \mathrm{~d}$ after first calving in the South. The percentage of censored records ranged from $40.1 \%$ in the South East to $44.6 \%$ in the North East.

Table 3 shows the relative risk of involuntary culling according to classification score for body traits in each geographical region. The effect of stature on culling risk was minimal, with a clear trend observed only in the West, where tall cows tended to have poorer longevity. Strength and body depth were slightly more important than stature, and scores of 10,15 , or 20 seemed to be optimal, with respect to survival, in most regions. Longevity of cows with extremely low scores (i.e., 5) was slightly impaired, but that of cows with high scores (i.e., 35,40 , or 45 ) was reduced significantly. In general, 
Table 3. Relative risk of involuntary culling according to region and linear score for body traits (relative risk of culling for cows scoring 25 was set to unity for each region and trait; a minimum of 50 uncensored failures were allowed per subclass).

\begin{tabular}{|c|c|c|c|c|c|c|c|c|c|c|}
\hline \multirow[b]{2}{*}{ Trait } & \multirow[b]{2}{*}{$\begin{array}{l}\text { Linear } \\
\text { score }\end{array}$} & \multicolumn{9}{|c|}{ Region } \\
\hline & & $\begin{array}{l}\text { North } \\
\text { east }\end{array}$ & $\begin{array}{l}\text { South } \\
\text { east }\end{array}$ & Central & $\begin{array}{l}\text { East } \\
\text { north } \\
\text { central }\end{array}$ & $\begin{array}{l}\text { West } \\
\text { north } \\
\text { central }\end{array}$ & South & $\begin{array}{l}\text { South } \\
\text { west }\end{array}$ & $\begin{array}{l}\text { North } \\
\text { west }\end{array}$ & West \\
\hline \multirow[t]{9}{*}{ Stature } & 5 & 0.95 & 0.98 & 0.94 & 1.04 & 0.72 & 0.99 & 0.97 & 0.98 & 0.95 \\
\hline & 10 & 0.99 & 1.02 & 1.12 & 1.02 & 1.01 & 1.01 & 1.03 & 0.88 & 0.94 \\
\hline & 15 & 0.96 & 0.94 & 0.98 & 1.02 & 0.99 & 0.96 & 1.02 & 0.97 & 0.95 \\
\hline & 20 & 0.96 & 0.95 & 0.99 & 0.99 & 1.00 & 0.97 & 0.99 & 0.95 & 0.95 \\
\hline & 25 & 1.00 & 1.00 & 1.00 & 1.00 & 1.00 & 1.00 & 1.00 & 1.00 & 1.00 \\
\hline & 30 & 0.98 & 1.00 & 1.02 & 1.01 & 0.92 & 1.04 & 1.06 & 0.98 & 1.02 \\
\hline & 35 & 0.99 & 1.04 & 1.03 & 1.01 & 0.95 & 1.03 & 1.09 & 1.01 & 1.04 \\
\hline & 40 & 0.98 & 1.06 & 1.02 & 1.00 & 1.01 & 1.08 & 1.08 & 0.98 & 1.12 \\
\hline & 45 & 0.98 & 0.98 & 1.03 & 1.00 & 0.85 & 1.03 & 1.03 & 1.08 & 1.17 \\
\hline \multirow[t]{9}{*}{ Strength } & 5 & 1.03 & 1.01 & 1.14 & 1.09 & 1.06 & 0.92 & 0.95 & 1.01 & 0.97 \\
\hline & 10 & 0.97 & 0.98 & 1.00 & 1.02 & 1.12 & 0.97 & 0.95 & 0.95 & 0.91 \\
\hline & 15 & 0.96 & 0.97 & 0.97 & 0.99 & 1.04 & 0.94 & 0.95 & 0.97 & 0.94 \\
\hline & 20 & 0.98 & 1.00 & 0.98 & 0.98 & 1.03 & 0.96 & 0.96 & 0.98 & 0.95 \\
\hline & 25 & 1.00 & 1.00 & 1.00 & 1.00 & 1.00 & 1.00 & 1.00 & 1.00 & 1.00 \\
\hline & 30 & 1.03 & 1.04 & 1.03 & 1.02 & 1.04 & 1.04 & 1.09 & 1.01 & 1.04 \\
\hline & 35 & 1.05 & 1.09 & 1.08 & 1.03 & 0.98 & 1.06 & 1.15 & 1.09 & 1.15 \\
\hline & 40 & 1.17 & 1.04 & 1.04 & 1.07 & 1.13 & 1.10 & 1.25 & 1.19 & 1.17 \\
\hline & 45 & 1.12 & & 1.30 & 1.16 & & & & & 1.02 \\
\hline \multirow[t]{9}{*}{ Body depth } & 5 & 0.96 & 1.01 & 1.12 & 1.04 & 1.02 & 0.84 & 0.93 & 1.01 & 0.93 \\
\hline & 10 & 0.93 & 0.91 & 0.95 & 0.97 & 1.08 & 0.89 & 0.85 & 0.93 & 0.89 \\
\hline & 15 & 0.92 & 0.95 & 0.95 & 0.95 & 1.01 & 0.88 & 0.93 & 0.93 & 0.91 \\
\hline & 20 & 0.96 & 0.96 & 0.96 & 0.97 & 0.95 & 0.91 & 0.93 & 0.96 & 0.95 \\
\hline & 25 & 1.00 & 1.00 & 1.00 & 1.00 & 1.00 & 1.00 & 1.00 & 1.00 & 1.00 \\
\hline & 30 & 1.03 & 1.07 & 1.03 & 1.04 & 1.02 & 1.02 & 1.10 & 1.07 & 1.08 \\
\hline & 35 & 1.08 & 1.05 & 1.11 & 1.07 & 1.00 & 1.08 & 1.18 & 1.07 & 1.15 \\
\hline & 40 & 1.12 & 1.31 & 1.12 & 1.05 & 1.24 & 1.15 & 1.32 & 1.25 & 1.23 \\
\hline & 45 & 1.24 & & & 1.13 & & & & & \\
\hline \multirow[t]{9}{*}{ Dairy form } & 5 & 1.06 & 1.14 & 1.24 & 1.07 & 1.22 & 1.16 & 1.14 & 1.00 & 1.00 \\
\hline & 10 & 0.96 & 0.97 & 0.98 & 0.94 & 1.01 & 0.94 & 0.99 & 0.94 & 0.94 \\
\hline & 15 & 0.93 & 0.93 & 0.95 & 0.93 & 1.02 & 0.92 & 0.97 & 0.93 & 0.90 \\
\hline & 20 & 0.96 & 0.96 & 0.96 & 0.94 & 1.01 & 0.91 & 0.93 & 0.94 & 0.95 \\
\hline & 25 & 1.00 & 1.00 & 1.00 & 1.00 & 1.00 & 1.00 & 1.00 & 1.00 & 1.00 \\
\hline & 30 & 1.06 & 1.08 & 1.05 & 1.05 & 1.07 & 1.07 & 1.04 & 1.05 & 1.05 \\
\hline & 35 & 1.13 & 1.17 & 1.16 & 1.12 & 1.10 & 1.14 & 1.17 & 1.15 & 1.13 \\
\hline & 40 & 1.25 & 1.32 & 1.23 & 1.29 & 1.33 & 1.09 & 1.14 & 1.25 & 1.25 \\
\hline & 45 & 1.39 & & 1.33 & 1.35 & & & & 1.52 & 1.22 \\
\hline
\end{tabular}

results of the present study confirm the lack of importance of body size as compared with other conformation traits with respect to cow longevity (Short and Lawlor, 1992; Larroque and Ducrocq, 1999). Dairy form scores of $\leq 5$ or $\geq 30$ were associated with reduced survival after voluntary culling because poor milk production was taken into account. Scores of $10,15,20$, or 25 were optimal in all regions, indicating that animals with extremely high observations for dairy character (or angularity) may suffer from impaired health or fertility, perhaps because of poor body condition (Bunger and Swalve, 1999).

The relationship between involuntary culling and rump traits is shown in Table 4. Neither trait had a strong impact on survival, as expected based on previous studies (Bunger and Swalve, 1999; Larroque and Ducrocq, 1999). Scores of 20, 25, or 30 for rump angle were associated with the lowest risk of culling in all regions, indicating an intermediate optimum for this trait. Results for rump width were similar to those of strength and body depth, with optimum scores ranging from 10 to 30 across regions and with high risk values associated with (quite uncommon) scores of 45 in several regions.

Relative risk estimates for feet and leg traits are shown in Table 5. Rear legs side view clearly displayed an intermediate optimum, with lowest risk values corresponding to scores of 20,25 , or 30 in all regions. Low scores (corresponding to straight legs) led to slightly higher risk of culling in virtually all regions, and high scores (corresponding to curved or "sickled" legs) were associated with a substantially higher risk of culling. The latter condition was particularly detrimental, with risk values from 1.42 to 1.51 in the North East, Central, 
Table 4. Relative risk of involuntary culling according to region and linear score for rump traits (relative risk of culling for cows scoring 25 was set to unity for each region and trait; a minimum of 50 uncensored failures were allowed per subclass).

\begin{tabular}{|c|c|c|c|c|c|c|c|c|c|}
\hline \multirow[b]{2}{*}{ Trait } & \multirow[b]{2}{*}{$\begin{array}{l}\text { Linear } \\
\text { score }\end{array}$} & \multicolumn{8}{|c|}{ Region } \\
\hline & & $\begin{array}{l}\text { North } \\
\text { east }\end{array}$ & $\begin{array}{l}\text { South } \\
\text { east }\end{array}$ & Central & $\begin{array}{l}\text { East } \\
\text { north } \\
\text { central }\end{array}$ & $\begin{array}{l}\text { West } \\
\text { north } \\
\text { central }\end{array}$ & South & $\begin{array}{l}\text { South } \\
\text { west }\end{array}$ & $\begin{array}{l}\text { North } \\
\text { west }\end{array}$ \\
\hline \multirow[t]{9}{*}{ Rump width } & 5 & 1.01 & 1.02 & 1.07 & 1.05 & 1.12 & 0.95 & 0.93 & 0.94 \\
\hline & 10 & 0.99 & 1.05 & 1.03 & 1.01 & 1.00 & 0.91 & 0.96 & 0.93 \\
\hline & 15 & 0.98 & 0.98 & 0.99 & 0.99 & 0.99 & 0.96 & 0.92 & 0.93 \\
\hline & 20 & 0.98 & 1.01 & 0.99 & 0.99 & 0.96 & 0.97 & 0.94 & 0.98 \\
\hline & 25 & 1.00 & 1.00 & 1.00 & 1.00 & 1.00 & 1.00 & 1.00 & 1.00 \\
\hline & 30 & 1.01 & 1.03 & 1.02 & 1.00 & 0.95 & 0.99 & 1.04 & 1.03 \\
\hline & 35 & 1.05 & 1.10 & 1.04 & 1.03 & 1.06 & 1.09 & 1.07 & 1.03 \\
\hline & 40 & 1.11 & 1.14 & 1.10 & 1.08 & 1.06 & 1.06 & 1.05 & 1.08 \\
\hline & 45 & 1.12 & 1.25 & 1.13 & 1.19 & 0.98 & 1.37 & 0.83 & 1.30 \\
\hline \multirow[t]{9}{*}{ Rump angle } & 5 & 1.23 & 1.18 & 1.19 & 1.31 & 1.21 & 1.18 & 1.19 & 1.10 \\
\hline & 10 & 1.13 & 1.06 & 1.10 & 1.09 & 1.09 & 1.02 & 1.08 & 0.99 \\
\hline & 15 & 1.06 & 1.06 & 1.07 & 1.05 & 1.01 & 0.99 & 1.05 & 1.01 \\
\hline & 20 & 1.01 & 1.03 & 1.02 & 1.01 & 0.99 & 0.97 & 1.02 & 0.99 \\
\hline & 25 & 1.00 & 1.00 & 1.00 & 1.00 & 1.00 & 1.00 & 1.00 & 1.00 \\
\hline & 30 & 1.02 & 1.04 & 1.02 & 1.03 & 0.98 & 0.99 & 1.01 & 0.98 \\
\hline & 35 & 1.06 & 1.05 & 1.06 & 1.07 & 1.00 & 1.01 & 1.06 & 0.99 \\
\hline & 40 & 1.09 & 1.11 & 1.13 & 1.07 & 1.20 & 1.02 & 1.08 & 1.00 \\
\hline & 45 & 1.18 & & 1.20 & 1.17 & & & & 1.03 \\
\hline
\end{tabular}

Table 5. Relative risk of involuntary culling according to region and linear score for foot and leg traits (relative risk of culling for cows scoring 25 was set to unity for each region and trait; a minimum of 50 uncensored failures were allowed per subclass).

\begin{tabular}{|c|c|c|c|c|c|c|c|c|c|c|}
\hline \multirow[b]{2}{*}{ Trait } & \multirow[b]{2}{*}{$\begin{array}{l}\text { Linear } \\
\text { score }\end{array}$} & \multicolumn{9}{|c|}{ Region } \\
\hline & & $\begin{array}{l}\text { North } \\
\text { east }\end{array}$ & $\begin{array}{l}\text { South } \\
\text { east }\end{array}$ & Central & $\begin{array}{l}\text { East } \\
\text { north } \\
\text { central }\end{array}$ & $\begin{array}{l}\text { West } \\
\text { north } \\
\text { central }\end{array}$ & South & $\begin{array}{l}\text { South } \\
\text { west }\end{array}$ & $\begin{array}{l}\text { North } \\
\text { west }\end{array}$ & West \\
\hline \multirow[t]{9}{*}{ Rear legs, side view } & 5 & 1.10 & 0.93 & 1.09 & 1.14 & 1.10 & 1.11 & 1.22 & 1.08 & 1.10 \\
\hline & 10 & 1.06 & 1.05 & 1.10 & 1.06 & 1.09 & 1.04 & 1.02 & 1.01 & 1.02 \\
\hline & 15 & 1.04 & 1.05 & 1.04 & 1.02 & 1.02 & 1.06 & 1.10 & 1.06 & 1.03 \\
\hline & 20 & 1.02 & 1.03 & 1.03 & 1.00 & 1.03 & 0.98 & 1.08 & 1.03 & 1.02 \\
\hline & 25 & 1.00 & 1.00 & 1.00 & 1.00 & 1.00 & 1.00 & 1.00 & 1.00 & 1.00 \\
\hline & 30 & 1.05 & 1.02 & 1.05 & 1.04 & 0.94 & 0.99 & 1.05 & 0.99 & 1.00 \\
\hline & 35 & 1.11 & 1.07 & 1.12 & 1.12 & 1.03 & 1.04 & 1.05 & 1.00 & 1.01 \\
\hline & 40 & 1.18 & 1.17 & 1.25 & 1.26 & 1.18 & 1.16 & 1.07 & 1.06 & 1.06 \\
\hline & 45 & 1.43 & 1.32 & 1.51 & 1.48 & 1.42 & 1.22 & 1.21 & 1.21 & 1.21 \\
\hline \multirow[t]{9}{*}{ Rear legs, rear view } & 5 & 1.25 & 1.20 & 1.35 & 1.31 & 1.35 & 1.19 & 1.11 & 1.18 & 1.13 \\
\hline & 10 & 1.10 & 1.07 & 1.15 & 1.14 & 1.19 & 1.09 & 0.97 & 1.06 & 1.03 \\
\hline & 15 & 1.06 & 1.05 & 1.07 & 1.09 & 1.06 & 1.01 & 0.99 & 1.03 & 1.00 \\
\hline & 20 & 1.03 & 1.01 & 1.01 & 1.03 & 1.08 & 1.01 & 1.00 & 1.05 & 1.02 \\
\hline & 25 & 1.00 & 1.00 & 1.00 & 1.00 & 1.00 & 1.00 & 1.00 & 1.00 & 1.00 \\
\hline & 30 & 0.99 & 0.97 & 0.99 & 1.00 & 0.96 & 1.02 & 0.97 & 1.03 & 0.99 \\
\hline & 35 & 0.97 & 1.01 & 0.95 & 0.95 & 0.97 & 1.08 & 0.97 & 1.04 & 1.03 \\
\hline & 40 & 0.94 & 1.00 & 0.96 & 0.95 & 1.01 & 1.15 & 0.96 & 1.10 & 1.02 \\
\hline & 45 & 0.96 & 1.03 & 0.88 & 1.01 & 0.87 & 0.98 & 1.06 & 1.04 & 1.01 \\
\hline \multirow{9}{*}{ Foot angle } & 5 & 1.26 & 1.19 & 1.39 & 1.30 & 1.21 & 1.04 & 1.06 & 1.08 & 1.09 \\
\hline & 10 & 1.12 & 1.09 & 1.13 & 1.16 & 1.17 & 1.08 & 1.02 & 1.05 & 1.01 \\
\hline & 15 & 1.06 & 1.04 & 1.05 & 1.07 & 1.08 & 1.02 & 0.98 & 0.99 & 1.02 \\
\hline & 20 & 1.03 & 1.01 & 1.02 & 1.02 & 1.03 & 0.98 & 0.97 & 1.00 & 0.99 \\
\hline & 25 & 1.00 & 1.00 & 1.00 & 1.00 & 1.00 & 1.00 & 1.00 & 1.00 & 1.00 \\
\hline & 30 & 1.00 & 0.98 & 0.97 & 0.99 & 1.05 & 1.00 & 0.98 & 0.96 & 0.99 \\
\hline & 35 & 1.01 & 0.99 & 0.97 & 0.99 & 0.99 & 0.99 & 0.98 & 1.00 & 1.00 \\
\hline & 40 & 1.02 & 0.98 & 0.95 & 0.99 & 0.93 & 1.04 & 0.97 & 1.01 & 1.08 \\
\hline & 45 & 1.05 & 0.93 & 0.98 & 1.05 & 0.96 & 1.05 & 0.91 & 0.99 & 1.05 \\
\hline
\end{tabular}


East North Central, and West North Central regions, where cows spend more time on concrete. In the South East, South, South West, North West, and West, the risk of culling for cows with extremely curved rear legs ranged from 1.21 to 1.32 . For rear legs rear view, however, optimal scores ranged from 15 to 45 , and this indicated that straighter rear legs (when viewed from the rear) tended to confer slightly greater longevity. Low scores (i.e., 5) had relative risk values ranging from 1.25 to 1.35 in the North East, Central, East North Central, and West North Central regions, and poor classification scores in the remaining (southern and western) regions led to risk values ranging from 1.11 to 1.2. Foot angle seemed to display a pattern of "diminishing returns" with respect to functional survival. Low foot angle scores led to risk ratios from 1.21 to 1.39 in the aforementioned northern regions, and similar scores in the western and southern regions had risk ratios ranging from 1.04 to 1.19. Optimum foot angle scores ranged from 20 to 45 across regions, and risk ratios for animals with extremely high classification scores were not significantly greater than those of animals with intermediate scores. The relative importance of feet and leg traits in previous studies has varied from moderately important (Bunger and Swalve, 1999) to relatively unimportant (Larroque and Ducrocq), perhaps because of difficulty in measuring these traits accurately under field conditions.

In Table 6, estimated risk ratios for the udder traits are shown. As in nearly all previous studies (Short and Lawlor, 1992; Larroque and Ducrocq, 1999; Schneider et al., 1999), low scores for fore udder attachment were associated with very high culling risk, with values ranging from 1.44 to 1.86 between regions. Scores of 10 or 15 were also detrimental, with respect to functional survival, and linear scores of 40 or 45 were optimal in all regions. Risk ratios associated with optimal scores were from 0.7 to 0.92 of those of cows with intermediate type scores. Risk ratios associated with low scores for rear udder height and width ranged from 1.22 to 1.59 and from 1.12 to 1.46 , respectively. Scores of 10,15 , or 20 also tended to confer poorer than average longevity, and scores of 25 to 40 were optimal in different regions. As expected based on previous studies (Short and Lawlor, 1992; Larroque and Ducrocq, 1999; Vollema et al., 2000), udder depth was the most important type trait with respect to functional longevity. The relative risk of involuntary culling for cows with low udder depth scores ranged from 1.61 to 2.92 times that of cows with intermediate scores. Udder depth scores of 40 or 45 were optimal in all regions, and the risk of involuntary culling for cows with these scores ranged from 0.66 to 0.81 times that of cows with intermediate scores. Udder cleft was also an important predictor of survival. Cows with low udder cleft scores had risk ratios ranging from 1.47 to 1.88 times those of cows with intermediate scores, indicating significant impairment of functional longevity. Unlike the other udder traits, however, high scores did not confer greater longevity than intermediate scores. Optimal udder cleft scores ranged from 30 to 40 across geographical regions.

Results for teat traits are shown in Table 7. Low scores for front teat placement, indicating wide placement, were associated with risk ratios ranging from 1.26 to 1.5 across regions, indicating a strong impact of this trait on functional longevity. Similar to udder cleft, however, high teat placement scores did not lead to greater survival when compared with intermediate scores, and scores ranging from 25 to 40 were optimal in various regions. High teat length scores, indicating long teats, were detrimental in all regions, with corresponding risk ratios of 1.02 to 1.29 . Scores ranging from 15 to 30 were optimal, depending on region, and the impact of this trait on longevity was clearly less than that of other mammary traits, as in previous studies (Larroque and Ducrocq, 1999; Schneider et al., 1999).

Relationships between involuntary culling and scores for the 5 major breakdowns are shown in Table 8. Mammary system scores were easily the most important with respect to survival, and low scores (i.e., 55) were associated with risk ratios of 1.18 to 1.49 across regions. Conversely, high scores (i.e., 90) corresponded to risk ratios that were 0.70 to 0.92 times as large as those corresponding to intermediate scores of 75. Mammary system scores of 85 or 90 (after rounding) were optimal in all geographical regions. Risk ratios for feet and legs score showed a clear relationship with cow survival. Scores of 85 or 90 were optimal in all regions except the West, where the impact of feet and legs score on longevity was minimal (risk ratios close to unity for all classification scores). Cows with low feet and legs scores had risk ratios that were 1.06 to 1.23 times those of cows with intermediate scores. Frame scores appeared to have a minimal relationship with functional survival. Optimal scores ranged from 65 to 90 in different regions. High scores tended to be preferred in the North East, Central, East North Central, and West North Central regions; trends in the South East and North West regions were negligible; and lower scores were favored in the South, South West, and West regions. These differences may reflect voluntary culling for (larger) frame size in some (smaller) herds in the northern states. Dairy character scores clearly displayed an intermediate optimum with respect to survival, after correcting for within-herd-year ranking for milk production. Optimal scores were 70, 75, or 80 in all regions. Cows with low scores (indicating a lack of dairy character) had estimated risk ratios $>1.4$ in the South East, 
Table 6. Relative risk of involuntary culling according to region and linear score for udder traits. (For ease of interpretation, the culling risk for cows scoring 25 was set to unity after statistical analysis, and results are reported for subclasses with $\geq 50$ uncensored failures.)

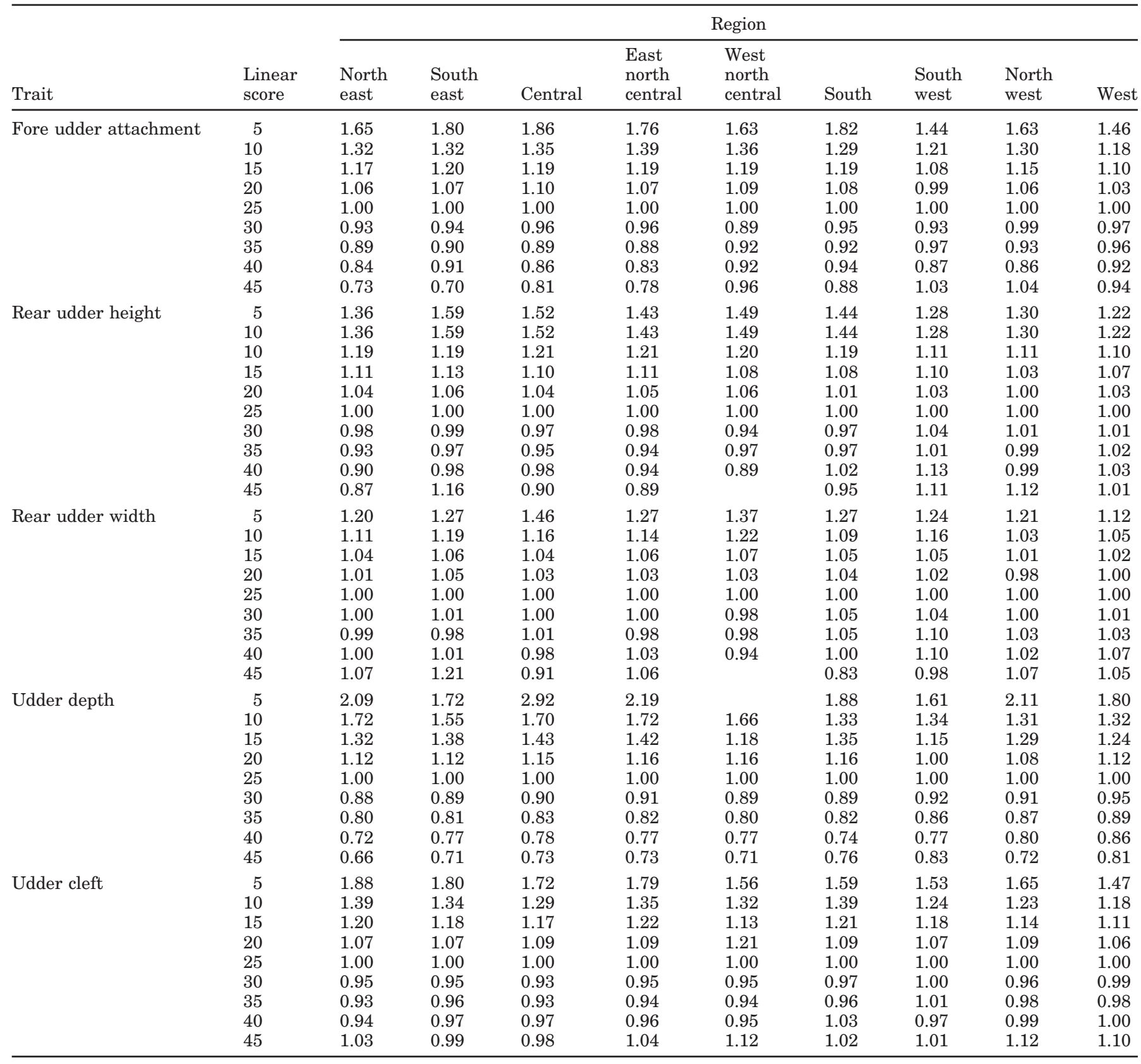

Central, and South regions, and low scores were slightly detrimental in all other regions except the South West. Conversely, cows with high scores (indicating extreme angularity) had risk ratios ranging from 1.19 to 1.37 in all regions, with the highest risk of culling in the South East, South West, North West, and West. This result seems to indicate that cows with extreme dairy character have impaired survival, particularly in large herds or in regions that are subject to heat stress. Conversely, it may indicate that less voluntary culling for (high) dairy character occurs in these regions than in (smaller) herds in the northern states. Lastly, body capacity scores tended to display a favorable relationship with functional longevity. Cows with extremely low scores for body capacity had estimated risk ratios ranging from 1.03 to 1.23 across regions, and cows with extremely high scores had risk ratios ranging from 0.7 to 1.15 . Optimum scores were 80,85 , or 90 in all regions, although the range in risk ratios was less than that of some other traits. This result seems to contradict the 
Table 7. Relative risk of involuntary culling according to region and linear score for teat traits. (For ease of interpretation, the culling risk for cows scoring 25 was set to unity after statistical analysis, and results are reported for subclasses with $\geq 50$ uncensored failures.)

\begin{tabular}{|c|c|c|c|c|c|c|c|c|c|c|}
\hline \multirow[b]{2}{*}{ Trait } & \multirow[b]{2}{*}{$\begin{array}{l}\text { Linear } \\
\text { score }\end{array}$} & \multicolumn{9}{|c|}{ Region } \\
\hline & & $\begin{array}{l}\text { North } \\
\text { east }\end{array}$ & $\begin{array}{l}\text { South } \\
\text { east }\end{array}$ & Central & $\begin{array}{l}\text { East } \\
\text { north } \\
\text { central }\end{array}$ & $\begin{array}{l}\text { West } \\
\text { north } \\
\text { central }\end{array}$ & South & $\begin{array}{l}\text { South } \\
\text { west }\end{array}$ & $\begin{array}{l}\text { North } \\
\text { west }\end{array}$ & West \\
\hline \multirow[t]{7}{*}{ Front teat placement } & 5 & 1.44 & 1.46 & 1.48 & 1.46 & 1.32 & 1.27 & 1.28 & 1.50 & 1.26 \\
\hline & 10 & 1.18 & 1.14 & 1.17 & 1.18 & 1.23 & 1.14 & 1.07 & 1.13 & 1.08 \\
\hline & 15 & 1.08 & 1.07 & 1.10 & 1.11 & 1.09 & 1.09 & 1.03 & 1.04 & 1.04 \\
\hline & 20 & 1.03 & 1.06 & 1.02 & 1.03 & 1.01 & 1.01 & 1.01 & 1.00 & 1.01 \\
\hline & 35 & 0.96 & 1.01 & 0.96 & 0.98 & 0.95 & 0.97 & 1.02 & 0.98 & 1.00 \\
\hline & 40 & 0.96 & 1.06 & 1.04 & 0.99 & 0.93 & 1.01 & 1.01 & 0.96 & 1.01 \\
\hline & 45 & 0.97 & 1.08 & 1.02 & 1.02 & 1.37 & 1.05 & 1.20 & 0.96 & 1.06 \\
\hline \multirow[t]{4}{*}{ Front teat length } & 5 & 0.92 & 1.07 & 1.07 & 0.97 & 1.11 & 1.04 & 1.19 & 0.97 & 0.99 \\
\hline & 10 & 0.96 & 1.04 & 1.02 & 0.98 & 1.11 & 1.08 & 1.02 & 1.00 & 0.97 \\
\hline & 15 & 0.96 & 1.02 & 1.01 & 0.98 & 1.05 & 1.01 & 1.01 & 1.01 & 0.98 \\
\hline & 45 & 1.21 & 1.25 & 1.20 & 1.26 & 1.29 & 1.02 & 1.12 & 1.17 & 1.22 \\
\hline
\end{tabular}

aforementioned relationships between longevity and stature, strength, body depth, and rump width. It should be noted that the Holstein Association USA now publishes a body size index based on these linear traits rather than body capacity scores.

Risk ratios corresponding to final (overall conformation) score are shown in Table 9. Scores of 85 or 90 (after rounding) were optimal in all regions, and risk ratios for these cows were only 0.61 to 0.95 as large as those for cows with intermediate scores of 75 . Conversely, low final scores were clearly detrimental in terms of functional survival. Low-scoring cows had risk ratios that were 1.43 to 2.17 times greater than the risk ratios for intermediate-scoring cows. Final score was more important, as a predictor of longevity, in the Central and West North Central regions (with risk ratios $>2$ ), although it was also quite important in the North East, South East, East North Central, South, and South West regions (all with risk ratios between 1.75 and 2). It is not surprising that final type score is correlated with longevity, because it represents a "composite" of all of the individual type traits, with udder traits, which are most closely related to survival, receiving the most weight.

\section{CONCLUSIONS}

As shown in previous studies, traits such as stature, rump width, and strength had minimal impact on functional survival, regardless of region, and traits such as udder depth, fore udder attachment, udder cleft, and rear leg set consistently influenced cow longevity. Mi- nor variation existed between regions in terms of the order of importance of various type traits. In particular, traits such as dairy form, feet and legs, and stature were more closely related with longevity in the North East, Central, East North Central, and West North Central regions. These differences may reflect a higher incidence of voluntary culling for these traits, particularly in smaller "pedigree" herds in these regions. They may also reflect different environmental or management demands on cattle in different regions, such as a greater proportion of time on concrete (e.g., in freestalls) in these regions, as compared with the South East, South, South West, North West, and West regions. Collectively, type traits were poorer predictors of longevity in regions such as the West or South West, where herds are much larger. Information provided in the present study could be used to create specific selection indices that would reflect the optimal conformation of dairy cows in each region in terms of functional longevity.

\section{ACKNOWLEDGMENTS}

The authors gratefully acknowledge financial support of the National Association of Animal Breeders, Columbia, MO; the Holstein Association USA, Brattleboro, VT; and the Babcock Institute for International Dairy Research and Development, Madison, WI. Technical assistance was kindly provided by Vincent $\mathrm{Du}$ crocq, and data were generously provided by the Holstein Association USA and the Animal Improvement Programs Laboratory, Agricultural Research Service, USDA, Beltsville, MD. 
Table 8. Relative risk of involuntary culling according to region and major breakdown. (For ease of interpretation, the culling risk for cows scoring 25 was set to unity after statistical analysis, and results are reported for subclasses with $\geq 50$ uncensored failures.)

\begin{tabular}{|c|c|c|c|c|c|c|c|c|c|c|}
\hline & & & & & & Region & & & & \\
\hline & $\begin{array}{l}\text { Linear } \\
\text { score }\end{array}$ & $\begin{array}{l}\text { North } \\
\text { east }\end{array}$ & $\begin{array}{l}\text { South } \\
\text { east }\end{array}$ & Central & $\begin{array}{l}\text { East } \\
\text { north } \\
\text { central }\end{array}$ & $\begin{array}{l}\text { West } \\
\text { north } \\
\text { central }\end{array}$ & South & $\begin{array}{l}\text { South } \\
\text { west }\end{array}$ & $\begin{array}{l}\text { North } \\
\text { west }\end{array}$ & West \\
\hline Mammary system & 55 & 1.47 & 1.42 & 1.49 & 1.47 & 1.38 & 1.30 & 1.18 & 1.41 & 1.24 \\
\hline & 60 & 1.35 & 1.32 & 1.39 & 1.34 & 1.40 & 1.33 & 1.19 & 1.20 & 1.18 \\
\hline & 65 & 1.23 & 1.23 & 1.27 & 1.21 & 1.29 & 1.22 & 1.15 & 1.17 & 1.13 \\
\hline & 70 & 1.11 & 1.11 & 1.15 & 1.12 & 1.17 & 1.09 & 1.08 & 1.10 & 1.08 \\
\hline & 75 & 1.00 & 1.00 & 1.00 & 1.00 & 1.00 & 1.00 & 1.00 & 1.00 & 1.00 \\
\hline & 80 & 0.91 & 0.93 & 0.91 & 0.90 & 0.88 & 0.94 & 0.97 & 0.93 & 0.95 \\
\hline & 85 & 0.80 & 0.86 & 0.84 & 0.81 & 0.78 & 0.86 & 0.91 & 0.89 & 0.91 \\
\hline & 90 & 0.70 & 0.72 & 0.72 & 0.72 & 0.78 & 0.74 & 0.92 & 0.77 & 0.87 \\
\hline Feet and legs & 55 & 1.17 & 1.17 & 1.23 & 1.22 & 1.20 & 1.17 & 1.09 & 1.06 & 1.07 \\
\hline & 60 & 1.14 & 1.08 & 1.15 & 1.23 & 1.13 & 1.05 & 1.04 & 1.20 & 1.02 \\
\hline & 65 & 1.09 & 1.10 & 1.15 & 1.12 & 1.25 & 1.15 & 1.09 & 1.08 & 1.02 \\
\hline & 70 & 1.05 & 1.06 & 1.07 & 1.07 & 1.07 & 1.04 & 0.96 & 1.01 & 1.01 \\
\hline & 75 & 1.00 & 1.00 & 1.00 & 1.00 & 1.00 & 1.00 & 1.00 & 1.00 & 1.00 \\
\hline & 80 & 0.96 & 0.97 & 0.93 & 0.95 & 0.06 & 0.98 & 0.98 & 0.98 & 0.97 \\
\hline & 85 & 0.90 & 0.93 & 0.90 & 0.93 & 0.84 & 0.93 & 0.99 & 0.99 & 0.99 \\
\hline & 90 & 0.86 & 0.87 & 0.82 & 0.89 & 0.71 & 0.96 & 0.93 & 0.92 & 1.01 \\
\hline Frame & 55 & 1.07 & 1.06 & 1.06 & 1.15 & 0.95 & 1.01 & 0.97 & 1.04 & 1.00 \\
\hline & 60 & 1.09 & 1.08 & 1.11 & 1.07 & 1.08 & 1.09 & 1.03 & 1.01 & 0.99 \\
\hline & 65 & 1.02 & 1.02 & 1.02 & 1.05 & 1.12 & 0.99 & 0.98 & 0.97 & 0.98 \\
\hline & 70 & 1.02 & 1.02 & 1.02 & 1.03 & 1.03 & 0.98 & 1.04 & 1.02 & 1.01 \\
\hline & 75 & 1.00 & 1.00 & 1.00 & 1.00 & 1.00 & 1.00 & 1.00 & 1.00 & 1.00 \\
\hline & 80 & 0.98 & 1.01 & 0.96 & 0.97 & 0.93 & 1.01 & 1.04 & 1.02 & 1.01 \\
\hline & 85 & 0.93 & 0.99 & 0.94 & 0.95 & 0.82 & 0.98 & 1.04 & 0.99 & 1.05 \\
\hline & 90 & 0.83 & 0.95 & 0.92 & 0.87 & 0.87 & 1.03 & 1.04 & 0.91 & 1.12 \\
\hline Dairy character & 55 & 1.26 & 1.46 & 1.48 & 1.17 & & 1.69 & & 1.10 & 1.12 \\
\hline & 60 & 1.39 & 1.26 & 1.26 & 1.13 & & 1.07 & & 0.94 & 1.02 \\
\hline & 65 & 1.08 & 1.17 & 1.12 & 1.03 & 0.93 & 1.02 & 1.12 & 1.04 & 1.09 \\
\hline & 70 & 1.02 & 1.00 & 1.09 & 1.02 & 1.07 & 1.05 & 0.97 & 1.05 & 1.04 \\
\hline & 75 & 1.00 & 1.00 & 1.00 & 1.00 & 1.00 & 1.00 & 1.00 & 1.00 & 1.00 \\
\hline & 80 & 1.02 & 1.04 & 1.01 & 1.02 & 0.99 & 1.01 & 0.99 & 1.04 & 1.06 \\
\hline & 85 & 1.08 & 1.13 & 1.10 & 1.12 & 1.02 & 1.12 & 1.07 & 1.15 & 1.16 \\
\hline & 90 & 1.21 & 1.34 & 1.25 & 1.27 & 1.14 & 1.19 & 1.23 & 1.31 & 1.37 \\
\hline Body capacity & 55 & 1.03 & 1.18 & 1.23 & 1.23 & & 1.17 & 1.09 & 1.06 & 1.05 \\
\hline & 60 & 1.00 & 1.08 & 1.15 & 1.22 & & 1.05 & 1.03 & 1.21 & 1.06 \\
\hline & 65 & 1.01 & 1.10 & 1.15 & 1.13 & 1.25 & 1.14 & 1.09 & 1.08 & 1.02 \\
\hline & 70 & 1.00 & 1.05 & 1.07 & 1.07 & 1.08 & 1.03 & 0.96 & 1.01 & 1.02 \\
\hline & 75 & 1.00 & 1.00 & 1.00 & 1.00 & 1.00 & 1.00 & 1.00 & 1.00 & 1.00 \\
\hline & 80 & 1.04 & 0.97 & 0.93 & 0.95 & 0.96 & 0.98 & 0.98 & 0.99 & 0.98 \\
\hline & 85 & 1.08 & 0.93 & 0.91 & 0.93 & 0.84 & 0.93 & 0.99 & 0.99 & 0.99 \\
\hline & 90 & 1.15 & 0.87 & 0.83 & 0.91 & 0.70 & 0.96 & 0.93 & 0.92 & 0.97 \\
\hline
\end{tabular}

Table 9. Relative risk of involuntary culling according to region and final score. (For ease of interpretation, the culling risk for cows scoring 25 was set to unity after statistical analysis, and results are reported for subclasses with $\geq 50$ uncensored failures.)

\begin{tabular}{lllllllllll}
\hline & \multicolumn{10}{c}{ Region } \\
\cline { 2 - 11 } & $\begin{array}{l}\text { Linear } \\
\text { score }\end{array}$ & $\begin{array}{l}\text { North } \\
\text { east }\end{array}$ & $\begin{array}{l}\text { South } \\
\text { east }\end{array}$ & Central & $\begin{array}{l}\text { East } \\
\text { north } \\
\text { central }\end{array}$ & $\begin{array}{l}\text { West } \\
\text { north } \\
\text { central }\end{array}$ & South & $\begin{array}{l}\text { South } \\
\text { west }\end{array}$ & $\begin{array}{l}\text { North } \\
\text { west }\end{array}$ & West \\
\hline Final score & 55 & 1.85 & 1.84 & 2.17 & 1.84 & 2.02 & 1.76 & 1.93 & 1.56 & 1.43 \\
& 60 & 1.44 & 1.41 & 1.48 & 1.52 & 1.29 & 1.41 & 1.38 & 1.31 & 1.21 \\
& 65 & 1.27 & 1.33 & 1.35 & 1.33 & 1.46 & 1.20 & 1.11 & 1.23 & 1.16 \\
& 70 & 1.14 & 1.13 & 1.12 & 1.12 & 1.14 & 1.07 & 1.02 & 1.06 & 1.02 \\
75 & 1.00 & 1.00 & 1.00 & 1.00 & 1.00 & 1.00 & 1.00 & 1.00 & 1.00 \\
& 80 & 0.93 & 0.92 & 0.90 & 0.90 & 0.91 & 0.91 & 0.97 & 0.95 & 0.97 \\
& 85 & 0.82 & 0.87 & 0.82 & 0.81 & 0.74 & 0.86 & 0.98 & 0.90 & 0.95 \\
& 0.75 & 0.77 & 0.73 & 0.82 & 0.62 & 0.61 & 0.61 & 0.56 & 1.11 \\
\hline
\end{tabular}




\section{REFERENCES}

Beilharz, R. G., B. G. Luxford, and J. I. Wilkinson. 1993. Quantitative genetics and evolution: Is our understanding of genetics sufficient to explain evolution? J. Anim. Breed. Genet. 110:161-170.

Bunger, A., and H. H. Swalve. 1999. Analysis of survival in dairy cows using supplementary data on type scores and housing systems. Pages 128-135 in Interbull Bull. No. 21. Interbull, Uppsala, Sweden.

Cruickshank, J., K. A. Weigel, M. R. Dentine, and B. W. Kirkpatrick. 2002. Indirect prediction of herd life in Guernsey dairy cattle. J. Dairy Sci. 85:1307-1313

Ducrocq, V. 1987. An analysis of length of productive life in dairy cattle. Ph.D. Diss., Cornell Univ., Ithaca, NY.

Ducrocq, V., and J. Sölkner. 1994. The Survival Kit - V3.0: A package for large analyses of survival data. In Proc. 5th World Congr. Genet. Appl. Livest. Prod., Guelph, ON, Canada 22:51-52.

Larroque, H., and V. Ducrocq. 1999. Phenotypic relationships between type and longevity in the Holstein breed. Pages 96-103 in Interbull Bull. No. 21. Interbull, Uppsala, Sweden.
Schneider, M. D. P., H. Monardes, and R. I. Cue. 1999. Effects of type traits on functional herd life in Holstein cows. Pages 111116 in Interbull Bull. No. 21. Interbull, Uppsala, Sweden.

Short, T. H., and T. J. Lawlor. 1992. Genetic parameters of conformation traits, milk yield, and herd life in Holsteins. J. Dairy Sci. 75:1987-1995.

Smith, S. P., and R. L. Quaas. 1984. Productive lifespan of bull progeny groups: Failure time analysis. J. Dairy Sci. 67:2999-3007.

Vollema, A. R., S. Van Der Beek, A. G. F. Harbers, G. De Jong. 2000. Genetic evaluation for longevity of Dutch dairy bulls. J. Dairy Sci. 83:2629-2639.

Vukasinovic, N. 1999. Application of survival analysis in breeding for longevity. Pages 3-10 in Interbull Bull. No. 21. Interbull, Uppsala, Sweden.

Weigel, K. A., T. J. Lawlor, Jr., P. M. VanRaden, and G. R. Wiggans. 1998. Use of correlated linear type and production data to supplement early predicted transmitting abilities for productive life. J. Dairy Sci. 81:2040-2044. 